\section{Allen, Jones and Hall: Black Social Entrepreneurship During the Early Republic}

\section{Donovan Forrest \\ Junior, Secondary Education/History}

In the years after the Revolutionary War, the cities of Philadelphia, Pennsylvania and Boston, Massachusetts saw a dramatic increase in the social entrepreneurship of African- Americans. The prevalent disenfranchisement of African-Americans in the era of the early Republic, the signing of the Declaration of Independence while most Blacks were enslaved and denied their basic right to life, liberty, and their pursuit of happiness, created an American society filled with discrimination and injustice. In the midst of hypocrisy, Black men rose to the occasion and founded organizations that provided Blacks with a sense of identity, comfort, and support. In the years following the enactment of the Constitution, African Americans found themselves to be disenfranchised socially, religiously, economically, and politically. A success for African-Americans nationwide was the establishing of the African Methodist Episcopal Church (AME) in 1817 by former slaves Richard Allen and Absalom Jones. This establishment of a Black religious institution by former slaves gave Blacks a spiritual oasis of hope in the midst of adversity and social discrimination. The founding of the Free African Society, The African Methodist Episcopal Church, and Black Freemasonry led the way for a stronger social identity amongst Blacks in the face of discrimination and adversity.
In the late 1700's and into the nineteenth century, Black men and women were marginalized economically, socially, and religiously. Servitude was common even in the northern city of Philadelphia where Richard Allen lived for a majority of his adult life. Allen's work as an activist was not entirely religious but in fact socially too. At the eve of the American Revolution, enslaved Africans made up nearly one-fifth of the population of the thirteen colonies. ${ }^{1}$ Mostly all Blacks living in the British Colonies were enslaved. ${ }^{2}$

In 1790, when Richard Allen was twenty-years old he was freed from his master's plantation in Delaware. As a young child and into his teenage years, Allen attended prayer meetings and church services in the Methodist church on a regular basis with permission from his master. Richard Allen's master, Stockley, was often criticized because of the religious freedom he allowed to his slaves. Allen often recalls his master saying to him and his brother; "Boys, if I am no good myself, I like to see you striving to be good." 3 Historical accounts labeled Stockley as a "good" master who was gracious and kind to his slaves. In his 1833 autobiography, Allen referred to his former, and unconverted master as a tender and humane man which he later referred to as a father figure. However, slavery as it was known to many enslaved men, women, and children created a different picture, one of intense pain, heartache, and denial of life, liberty, and each enslaved person's humanity. In Marcia M. Matthew's book "Richard Allen," she reflected on Allen's experiences as an enslaved man in Delaware and his experience watching to a freeborn Methodist and abolitionist preach about the sin of slavery to an angry group of pro-slavery men. ${ }^{4}$ 
Rev. Richard Allen spent a majority of his free years as a freeman preaching as a circuit preacher in Pennsylvania and Maryland until he settled in Philadelphia to establish The Free African Society. In his autobiography entitled The Life, Experience and Gospel Labours of the Rt. Rev. Richard Allen, Allen wrote on the backlash that he as well as other blacks experienced as members of the American Methodist Church. In his account, Blacks were pulled off their knees while they prayed, which prompted leaders such as Absalom Jones, William White, and Dorus Ginnings to erect a place of worship for colored men and women.
"The elder said, "let us pray." We had not been long upon our knees before I heard considerable scuffling and low talking. I raised my head up and saw one of the trustees, H-M-, having hold of the Rev. Absalom Jones, pulling him up off his knees, and saying, "you must get up-you must not kneel here." Mr. Jones replied. "Wait until the prayer is over." Mr. H-M-said "No, you must get up now, or I will call for aid and force you away." 5

\begin{abstract}
Allen was known to be modest but stubborn. During the late 1700s, Blacks free or enslaved had to concede and defer to white authority in order to survive in a society where they were largely disenfranchised. Allen established the Free African Society in 1787 , which was largely criticized by whites in Philadelphia during the Yellow Fever Epidemic.
\end{abstract}

"We have many unprovoked enemies, who begrudge us the liberty we enjoy, and we are glad to hear of any complaint against our color, be it just or unjust; in consequence of which we are more earnestly endeavoring all in our power to warn, rebuke and exhort our African friends, to keep a conscience void of offense towards God and man; and, at the same time, would not be backward to interfere, when stigmas or oppression appear pointed at, or attempted against them, unjustly; and we are confident,we shall stand justified in the sight of the candid and judicious for such conduct." 7

In essence, Richard Allen and Absalom Jones were on the forefront for change in Philadelphia through their heavy involvement in abolitionism and other forms of social activism. Both men as well as Prince Hall, the founder of Black Freemasonry were actively engaged in advocating for Black equality in the British Colonies. The struggle for liberty and racial equality were as common in the early republic as they were in the years leading up to the United States Civil War.

As the first minister of the African Methodist Episcopal Church, Absalom Jones was largely recognized in the black community by his dedication to rehabilitating the sick and ministering to the dying during the Yellow Fever Epidemic of 1793. Endeared by a large part of the Black population and because of his positive reputation among his fellow Philadelphians, Jones was pardoned by Episcopalian officials from having to meet the Greek and Latin requirement to be a minister. In the midst of the founding of the First African Church in Philadelphia, Jones wrote, "to arise out of the dust and shake ourselves, and throw off that servile fear, that the habit of oppression 
and bondage trained us up in." ${ }^{8}$ Both Jones and Allen were instructed by Quaker teacher Anthony Benezet. Benezet challenged the doctrine that Blacks were inferior and that Africa had produced barbarism. Benezet believed that Africa had produced respectable cultures, and that it was the environment and condition of slavery that transformed Africans into degraded human beings. ${ }^{9}$ These teachings inspired both Allen and Jones and other Philadelphia Blacks to increase their accomplishments following the Revolution.

Throughout his tenure as a preacher, leader, and social activist, Allen opposed the slave trade and slavery. As a social entrepreneur, Allen published numerous articles on the "sin" of slavery and targeted many slaveholders for what many believed was a crime against humanity. Both Richard Allen and Absalom Jones verbally sued political leaders and liberty activists for their part in the slave trade. In 1790s, the news of the successful Haitian Slave Rebellion had reached the ears of nearly everyone in Philadelphia. Former masters of Haitian slaves sought amnesty in Philadelphia and the anti-slavery discussion was in full effect.

In his address to Thomas Jefferson, the slaveholding founding father of the United States and avid revolutionary for freedom, Allen wrote: "If you love your children, if you love your country, if you love the God of love, clear your hands from slaves, burden not your children or country with them."10 Jefferson wrote in his Notes on the State of Virginia, that there was an existing dilemma in the minds of some slave masters. The dilemma was that although the American Revolution created a sense of American pride that was centered around the prospect of liberty, white slave owners feared the possibility of blacks becoming equal to them. There was much controversy over what total emancipation would mean for America. Allen also gave Jefferson a solution to Jefferson's fear that freeing blacks would mean a race war would ensue. "Why not retain and incorporate the Blacks into the State?" Jefferson responded that "deep-rooted prejudices entertained by the whites," and the "10,000 recollections by blacks of the injuries they have sustained." essence, Jefferson concluded that free Blacks would execute revenge on their former slave masters and destroy the early Republic. Allen also maintained that freed men and women would be grateful towards their liberators. ${ }^{12}$ In his sermon on the Abolition of the International Slave Trade in 1808, Absalom Jones the first pastor and co-founder of the African Methodist Episcopal Church, preached a sermon celebrating the day. Jones hoped that the day the International Slave Trade was abolished would be remembered as a day for Blacks and abolitionists to celebrate for years to come. Jones also urged freed Blacks to never forget their humble beginnings.

"Let us conduct ourselves in a manner as to furnish no cause of regret to the deliverers of our nation, for their kindness to us. Let us constantly remember the rock whence we were hewn, and the pit whence we were digged. Pride was not made for man, in any situation; and still less, for persons who have recently emerged from bondage. The Jews, after they entered the promised land, were commanded, when they offered sacrifices to the Lord, never forget their humble origin; and hence, part of the worship that 
accompanied their sacrifices consisted in publicly and privately, to acknowledge, that an African slave, ready to perish, was our father or our grandfather." 13

In essence, Jones preached to his congregants that freed Africans were not to seek vengeance but be grateful for their improved conditions.

Allen also worked with the Pennsylvania Abolition Society in dealing with his attitudes towards the institution of slavery. A common belief among white abolitionists of the early republic was that free Blacks still needed to be under the supervision of whites as far as their moral well-being is concerned. PAS President Benjamin Franklin believed that Blacks had been freed from slavery as "machines" and "animals." Also stating that: "freedom may often prove a misfortune to [the slave] himself and prejudicial to society"--- unless white reformers remained their moral overseers." ${ }^{14}$ Despite the efforts made by Allen to push the agenda of abolitionism throughout the American Republic, racist and discriminatory beliefs were still engrained in the American daily social milieu. Benjamin Rush, a United States founding father, physician, and prominent figure of the early republic spoke of dark pigmentation as a physical ailment. Rush urged that whites should pity their Black counterparts until they were liberated of their sickness.

In the decades following the Revolutionary War, Philadelphia was seen as a city of increased economic opportunities for whites as well as free Blacks. The Delaware River was a hotspot for trade and lenders granted loans to eligible Blacks and Whites for housing and was free of the discrimination in the housing market that later plagued the same city over one-hundred years later. Richard Allen and Absalom Jones both lived amongst whites in the city's river district. Allen lived a few blocks from co-founder of the African Methodist Episcopal Church Absalom Jones. Allen and Jones then established their church Mother Bethel African Methodist Episcopal Church a few blocks from Independence Hall where America's founding fathers Jefferson, Washington, and Adams signed the Declaration of Independence a few decades before. ${ }^{15}$ Philadelphia during the late eighteenth century as Allen recalled was a city of large homogenous nature. Blacks from the revolutionary Island of Haiti as well as immigrants from the West Indies, Northern Europe and Africa found their home in the bustling center of international commerce in the City of Philadelphia.

In 1793, the recent outbreak of Yellow Fever caused significant casualties in the City of Brotherly Love. Among those who were infected was Allen who was admitted to Bush Hill Hospital located north of what is today Center City, in late September and remained until late November of the same year. ${ }^{16}$ "Fifty-five residents were dead by the end of the year (out of 708)"17 in Allen's Spruce Street Neighborhood. Black residents were highly susceptible to more health risks because they did not have the means to leave their quarantined area. ${ }^{18}$ With Blacks recovering at a slower rate than whites, Black aid workers under the supervision of Allen and Jones visited yellow-fever victims and their families. Allen and his team nursed sick victims of the epidemic back to health and 
gave the deceased proper burials. ${ }^{19}$ Allen and Jones' Free African Society led the way for mutual aid organizations for Blacks in the upcoming decades and following centuries. As an organization that provided health assistance to victims of the Yellow Fever Epidemic of 1793, The Free African Society gained the trust of the Black community and Philadelphia and encouraged more free Blacks to attend religious services led by Allen.

Philadelphia's Free Black population began to increase with the abolition of slavery in northern part of the United States in 1804. Similar to many non-profits in Philadelphia in the twenty-first century, the Free African Society sought to improve urban conditions for free Blacks. In essence, the growth of the Free African Society can be attributed to Absalom Jones' preaching and Allen's aid to those in need at St. George's Methodist Episcopal Church. ${ }^{20}$ Prior to the American Revolution, and the establishment of the Free African Society, Philadelphia's free and enslaved Black population married, were baptized, and congregated at the city's Anglican churches. Initially, the Black congregants of the Anglican Church sought after Anglican beliefs for religious instruction, however, by the 1780 s, they began to flock to the recently established Methodist Episcopal Church. ${ }^{21}$ Shortly after their transferring of denominations, Black congregants of the Methodist Church felt welcome and accepted. ${ }^{22}$ One of the first historians of the African Episcopal Church wrote: "and being despised and persecuted as religious enthusiasts, their sympathies naturally turned towards the lowly, who like themselves, were of small estimate in the sight of worldly greatness. ${ }^{23}$ The anti-slavery views of Episcopal Church founder John Wesley contributed to the initial treatment of Blacks and the opposition against the slave trade, and slave holding. Slaveholders were also restricted from holding church offices. ${ }^{24}$

In 1794, the African Methodist Episcopal Church was founded ${ }^{25}$ as an extension of the spiritual efforts of the Free Black Society in the early eighteenth century. Due to the discrimination that free Blacks faced in the Methodist Episcopal Church, members decided to transform their congregation of the Free African Society into a church that Blacks could feel safe and welcome in. Upon Allen's arrival in Philadelphia, he sold dried goods, manufactured and sold shoes, and cleaned chimneys. Allen also served as an Assistant Minister at St. George's Methodist Episcopal Church. After almost a year of worshiping in the Methodist Episcopal Church, Allen as well as other free Blacks were told to move to the balcony. ${ }^{26}$ After countless forms of discrimination ensued, the African American congregation at St. George's left and worked to found their own church free of discrimination. As a result Absalom Jones called on free Blacks in other Northern Cities to form their own denomination based off of the religious teachings of John Wesley. In essence, the success of the African Methodist Church ensued jealousy amongst white congregants of the Methodist Episcopal Church. In an attempt to control the new church's congregation, the Methodist Episcopal Church attempted to sue Allen. The lawsuit was successful however, Allen and his congregants quickly raised the necessary funds and rebought their property. 
Also in the late eighteenth century in Boston, Massachusetts, Black men rose to the occasion to found organizations that would provide Blacks with a sense of identity, belonging, and pride. One example of these men was Prince Hall, an avid advocate of abolition, Black empowerment, and education. Hall founded Black Freemasonry, a secret society in Boston, Massachusetts and made it possible for Blacks worldwide to enjoy the all of the privileges of freemasonry. ${ }^{27}$ In an address to his fellow brothers of the African Lodge, Hall spoke:

"Another thing which is the duty of a Mason is, that he pays a strict regard to the stated meetings of the Lodge, for masonry is of a progressive nature, and must be attended to if ever he intends to be a good Mason; for the man that thinks that because he hath been made a Mason, and is called so, and at the same time will wilfully neglect to attend his Lodge, he may be assured he will never make a good Mason, nor ought he to be looked upon as a good member of the craft. For if his example was followed, where would be the Lodge; and besides what a disgrace is it, when we are at our set meetings, to hear that one of our members is at a drinking house, or at a card table, or in some worse company, this brings disgrace on the Craft: Again there are some that attend the Lodge in such a manner that sometimes their absence would be better than their Company (I would not here be understood a brother in disguise, for such an one hath no business on a level floor) for if he hath been displeased abroad or at home, the least thing that is spoken that he thinks not right, or in the least offends him, he will raise his temper to such a height as to destroy the harmony of the whole Lodge; but we have a remedy and every officer ought to see it put in execution." 28

As the founder of Black Freemasonry, Prince Hall often addressed his lodge members on the acceptable behaviors of members of Freemasonry. From the founding of the African Lodge to the twenty-first Century, members of Freemasonry conduct themselves as men knowledgeable of the needs of their community and active in community service and activism.

Hall also played a large role in abolitionism and other anti-slavery causes in the North. One example of Hall's involvement in the anti-slave trade in the early republic was his interception of the kidnapping of three Blacks into slavery in the West Indies. In February 1788, Prince Hall along with twenty other of his Lodge members petitioned the Commonwealth of Massachusetts to intervene in the kidnapping of three free Black men. The news of the kidnapping circulated throughout the city and to white Masons. One of the three men that were kidnapped was a freemason. ${ }^{29}$ Jeremy Belknap, a historian during the early Republic praised Hall and his comrades for their camaraderie. "Really, my dear sir, I felt, and do still feel, from this circumstance, a pleasure which is a rich compensation for all the curses of the whole tribe of African traders, aided by the distillers, which have been liberally bestowed on the clergy of this town for their agency in the above petition." 30 In 1788, John Marant became Grand Master of the African Lodge of Freemasonry. ${ }^{31}$ In Marant's address to a mixed group of Masons he 
discussed the slave of imperialism and the enslavement of fellow men and women. "To colonize, invade, enslave, or abuse the "nations" of this "African Ethiopia," even those scattered across the African diaspora, is to act against the order of Creation." 32

One success for the African American community was the founding of the African Methodist Episcopal Church in 1817 by former slaves Richard Allen and Absalom Jones. The establishment of a religious institution by former slaves gave Blacks a spiritual oasis of hope in the midst of adversity. In addition, the founding of the free African Society, the African Methodist Episcopal Church, and Black Freemasonry led the way for a stronger racial and cultural identity for Blacks in the face of

\section{Notes}

${ }^{1}$ Warren Smith, John Wesley \& Slavery (Nashville: Abingdon Press, 1986), 28.

${ }^{2}$ Ibid.

${ }^{3}$ Marcia Matthews, Richard Allen (BaltimoreDublin: Helicon, 1963), 24-25.

${ }^{4}$ Ibid, 4.

${ }^{5}$ Richard Allen, “The Life, Experience, and Gospel Labors of the Rt. Rev. Richard Allen...,"

(Philadelphia: Martin \& Boden, Printers, 1833), 5.

${ }^{6}$ Richard Newman, Freedom's Prophet (New York and London: New York University Press), 6.

7 Ibid, 79.

${ }^{8}$ Gary B. Nash, “Absalom Jones: Free Black Leader, "Struggle and Survival in Colonial America (1981):184. discrimination and adversity. In essence, the years after the Revolutionary War saw a significant increase in the social entrepreneurship of Black men. In the midst of a split nation over the issue of the equality and liberty for all men regardless of skin color, and the marginalization of Blacks in the early Republic, the enslavement of Blacks created an African society that was largely defined by injustice and discrimination. However, in the midst of this hypocrisy and untruth, three African American men named Richard Allen, Absalom Jones, and Prince Hall answered the call to found organizations that provided Blacks with a sense of identity, comfort, and support.

${ }^{9}$ Ibid.

${ }^{10}$ Newman, Freedom's Prophet (New York and London: New York University Press), 107.

${ }^{11}$ Ibid, 109.

${ }^{12}$ Ibid.

${ }^{13}$ Absalom Jones, Sermon on the Abolition of the International Slave Trade (1808).

${ }^{14}$ Newman, Freedom's Prophet (New York and London: New York University Press), 110.

${ }^{15}$ Ibid, 81.

${ }^{16}$ Ibid, 85.

${ }^{17}$ Ibid.

${ }^{18}$ Ibid.

${ }^{19}$ Richard Newman, Freedom's Prophet (New York and London: New York University Press), 90.

${ }^{20}$ Ibid.

${ }^{21}$ Gary B. Nash, “Absalom Jones: Free Black Leader, "Struggle and Survival in Colonial America (1981): 179.

${ }^{22}$ Ibid.

${ }^{23}$ Ibid. 
${ }^{24}$ Ibid.

${ }^{25}$ Ibid.

${ }^{26}$ Ibid.

${ }^{27}$ Ibid.

${ }^{28}$ Ibid.

${ }^{29}$ Joanna Brooks, "Prince Hall, Freemasonry, and Genealogy," African American Review (2000): 197.

${ }^{30}$ Ibid.

31 "Prince Hall Freemasonry," Wikipedia.org, accessed November 10, 2016,

https://en.wikipedia.org/wiki/Prince Hall Free

masonry.

${ }^{32}$ Brooks, 197.
Newman, Richard. Freedom's Prophet New York and London: New York University Press. (2008)

Smith, Warren. John Wesley \& Slavery Nashville: Abingdon Press. (1986)

"Prince Hall Freemasonry," Wikipedia.org, last modified December 5, 2016.https://en.wikipedia .org/wiki/Prince Hall Fr eemasonry

\section{Bibliography}

Allen, Richard. The Life, Experience, and Gospel Labors of the Rt. Rev. Richard Allen "Philadelphia: Martin \& Boden, Printers. (1833)

Brooks, Joanna. Prince Hall, Freemasonry, and Genealogy Vol.34, No.2 . Indiana State University. (2000)

Hall, Prince. A Charge Delivered to the Brethren of the African Lodge (1792)

Jones, Absalom. Sermon on the Abolition of the International Slave Trade (1808)

Matthews, Marcia. Richard Allen

Baltimore-Dublin: Helicon. (1963)

Nash, Gary B. Absalom Jones: Free Black Leader: Struggle and Survival in Colonial America. University of California Press. (1981) 